Vol. 2, No. 2, 2015

\author{
O. Ye. Kuzmin \\ Doctor of Economics, Professor, \\ Lviv Polytechnic National University
}

O. Telishevska

Postgraduate student,

Lviv National University of Veterinary Medicine and Biotechnology named after S. Z. Gzhytskiy

\title{
METHODOLOGY OF CALCULATIONS OF LOGISTIC COSTS AND CHARGES FOR DELIVERY
}

\begin{abstract}
The development of Ukrainian economics observed in the last years and its orientation towards the integration into the world economics community, as well as large-scale introduction of market relations require the radical structural changes of economic potential of subjects of entrepreneurial activity and adequate policy directed towards the increase in the efficiency of their economic activity. The improvement of the management of material flows, flows of funds and information flows contains the considerable potential of growth of efficiency of enterprise activity as a result of application of new progressive methods and approaches. Among such approaches the main place is occupied by logistics which begins to develop dramatically in Ukraine.

The modern nature of market, target orientation of production and the distribution of products according to consumers' requests determine the necessity of searching extra possibilities for decreasing expenditures and product costs, as well as improving service levels for the enhancement of the efficiency of enterprise activity.

For domestic enterprises of different branches logistics costs make up the considerable part of general costs. Logistics costs are the expenditures created as the result of information flows, flows of funds and material flows. It is no exaggeration to say that logistics is a comprehensive process in business, since every movement, search or bargain is cost-based, without regard for logistic characteristics.
\end{abstract}

With the help of logistic calculations it is possible to 1) determine the expenditures on the purchase process, transportation, warehousing; 2) predict the budget of future periods; 3) compare and analyze the characteristics of logistics activity.

In the conditions of transient economics, that is, fierce competition, financial volatility and spread of the corrupt practices, the problem of the optimization of the enterprise expenditures arises. So, the reduction of logistics costs is the top-priority activity aimed at the stable operation of the enterprise.

The necessity of the appropriate response of management processes to changes in the functioning conditions and improvement of delivery and marketing causes the stable interest of domestic manufacturers in the process of maintenance supply and production distribution as important constituents of enterprise activity. Taking into account the fact that the production program of the enterprise and, naturally, the results of its economic activity depends on the efficient organization of supply and marketing, we can state that the entire investigation of these processes is extremely urgent.

Key words: enterprise, method, logistic procurement charges, party of delivery, strategic decisions, export-import operations.

The analysis of recent investigations. Many Ukrainian and foreign scientists have devoted their works to the problem of calculating logistic costs. They are, for example, A. Gadzhynskiy, A. Kalchenko, O. Trydid, O. Oklander, A. Albekova, V. Petrova, R. Brealey and others. But the uncertainty of notions and methodologies of calculations still exists nowadays. This situation can be explained by the fact that logistics has been introduced into Ukrainian enterprises rather not long ago and there are no unified techniques for the calculations of basic logistic characteristics.

As A. Kalchenko states, the main tools of logistics are the rate of stock turnover, the turnover of commodities, general expenditures on maintenance supplies, per cent of complying with the order, logistics costs as a percent of general costs, the part of own transport facilities in the automobile park, the risks of stocks [1]. Also, in our opinion, the MOB problem ("make or buy") is very important. Having analyzed the activity of domestic and foreign enterprises, we can realize that the better logistics is developed, the more often entrepreneurs refuse the production of utilities and attachments [2].

Hence it follows that one of the core problems of the logistics development is the determination of the structure and methodologies 


\section{O. Ye. Kuzmin, O. Telishevska}

of the calculation of logistics costs. As it is known, business accountings do not contain the logistic items, because they are included into invoices and it makes the identification of logistics costs more difficult. So, the investigation and analysis of the experience of calculating logistic costs gained by Ukrainian and foreign enterprises is a first-rate and important task.

The aim of the article is the investigation of the methodology of calculating logistic and supply costs of the enterprise.

The subjects of investigation are theoretical and methodological questions of the optimization of stock control in the spheres of supply and marketing (distribution).

The modern theories of market economics, management, marketing and logistics, as well as scientific doctrines and theories of Ukrainian and foreign scholars have become the theoretical and methodological basis of the performed investigations.

Statement of investigations. Logistics is the management of the flow of goods between the point of origin and the point of consumption. It considers the chain of supply, consisting of the complex of services or "links", each of them performing its functions, beginning from the manufacturer up to the consumer.

Developed logistics tends to control the whole supply chain. The core aspect of the situation is the fact, that logistics is the system of management of the supply chain and concerns different kinds of activity (links), providing services with value added.

Logistics is ruled by demand, and so prospective consumers of logistic services will determine the level of the development of this segment of economics in Ukraine. Expected increase in these services is based on two main factors: latent and new (future) demand. Latent demand is the existed demand which has not manifested itself yet because of the lack of optimal conditions for its development. The second factor is caused by absolutely new business launched by "new players", which are coming to the market simultaneously with the general economic development. For the near-term and medium outlook the main source of generating and further increasing of the demand will be its latent component.

One of the main problems of the development of logistics in Ukraine is the fact that most customers who need its services do not have enough knowledge about cost items they should take into account considering different supply chains, as well as alternative approaches which could reduce costs for logistic operations.

Most companies seldom count their warehousing costs, but they should be concerned about them, because the principal cost savings in the sphere of logistics of the higher level are accumulated due to the savings at the stage of inventory holdings. Besides, there is a great difference between the competence in this sphere international companies have and domestic companies whose competence and presence on the market is much lower [3].

Careful attention to logistics is caused by its capability to provide better efficiency of enterprise functioning. Logistics costs which are inseparably linked with functioning of the logistic system of the enterprise are formed in the different spheres, namely, supply, manufacturing and distribution. This makes the efficient management more difficult. So, at the enterprises the thorny problem of creating the informational support for the control of the logistics costs, that is, the methodology of accounting these costs, adapted to the National accounting standards of Ukraine as a basis for management decisions in the sphere of logistics [4] occurs.

For the majority of the industrial enterprises and wholesale and retail trade enterprises the logistic processes make up from $5 \%$ to $45 \%$ of sales volume depending on the kind of business, the geographical extent of its operation, the correlation between weighted estimator and price structure of the material resources and finished product. The part of logistics costs grows if the supply chain becomes more complex, if the system of purchase orders is changing, or the demands of the customers become stronger. But the most important feature of the logistics costs is the fact that they are not marked out in traditional accounting systems, but are treated as fixed charges, that is, are considered to be stable parts of invoices among other costs. So their correct identification, estimation and timely efficient management becomes much more difficult within the limits of total costs of the enterprise and control process as well [5].

Besides, the tendency for logistics costs to increase in comparison with the increase in income and prime costs, and providing the efficient 


\section{Methodology of calculations of logistic costs and charges for delivery}

management in the conditions of intense competition causes the practical importance and urgency of the development of mechanisms of identification, analysis and estimation of logistics costs aimed at increasing the efficiency of the logistics system at the enterprise.

So, for the selection of the logistics costs it is necessary to consider them according to the classification features, what will give the opportunity either to structure logistics costs or to plan the necessary rolling stock and the structure of the costs for the future, take account, analyze, control and regulate their amount and level at the conditions of particular calculation, reveal the reserves of the optimization of logistics costs in the logistic chains, as well as provide the efficient management from a position of general efficiency of the industrial enterprise operation.

Practically every company in any sphere of activity needs a logistic department. It can perform different functions according to specialization.

Big companies usually realize logistic functions at the independent logistic department. It employs all necessary specialists competent in this field. It can include drivers, traffic controllers, ordinary specialists in logistics and top managers. Smaller organizations confined themselves to creating small departments or even assigning individual employees, that can perform the functions of specialists in logistics and are employed at the department close to logistics, namely, traffic department, warehouse etc. Sometimes the logistic department can provide the management of external relations or is concerned with customs clearance. The manager providing foreign economic activities is occupied with document circulation related to sale or delivery, arranges relations with transportation companies, suppliers, insurance companies, banks etc.

The logistic department cannot be considered an auxiliary section. This activity is essential for every company. There are certain enterprises providing services in this sphere. They organize logistic activities for other companies.

LEONI Wiring Systems UA $(\mathrm{GmbH})$ is a subsidiary company of German enterprise Leoni AG which is an international manufacturer and supplier of wires, cables and cable systems for transport facilities on the world market. The customers of LEONI in Stryj (Ukraine) are the well-known car manufacturers of the world like Opel, Porsche, Volkswagen, Audi, Lamborghini and others.
The logistic department of the enterprise is subdivided into several sections.

MAWI - stock rotation section. The functions of accredited representatives of the enterprise are: control over wholesale inventories; material security; purchase orders and delivery of materials. For the improvement of enterprise operation the professionals of the German enterprise Leoni Kitzingen designed a FORS program in 1990. This system allows them to trace the movements of materials and finished products at all stages from delivery to shipment. The warehouse employees receive goods together with labels, which contain all necessary information including package, quantity, the supplier's number and assemblies and then record these data into the system.

Receiving inspection department check the conformity of materials, stamp and transfer to the warehouse PA. The materials are packed into containers KABA for convenience and saving the storage space and than transferred to warehouse KA intended for unpacked assemblies. At this warehouse every package with parts has its label developed by the system Kanban. Employees need the label Kanban for the improvement of the quality and time saving while performing their duties; it is valid for 8 hours. The supply of the assemblies is calculated for 5 days. At the case of downtime the supplier should inform the customer and indicate all possible costs occurring in this situation. The supplier is informed about the amount of indebtedness because of missing terms, quality and quantity of a given material. Every amount of indebtedness is registered in the quality department.

Costs of MAWI department: payment for materials, costs for damages paid by the LEONI employees (Stryj); reclamation costs; costs for downtime of assemblies; additional transportation costs occurring due to reclamations, damages and insufficient quantity of materials; reproductive costs on stationery. There are some downtime or reclamation costs (10 Euro per downtime hour). Additional transportation costs are associated with the order of urgent transportation services, for example, the most often used air transport and hand carry, or the service of delivery by hand. Differentiated costs mean the inappropriate quantity or description of goods in the documents as opposed to the really supplied materials. The differentiation of supply is recorded in the accounting department. The responsibility for the differentiated costs depends on the conditions of delivery. 


\section{O. Ye. Kuzmin, O. Telishevska}

LEONI operates on the basis of Incoterms (International commerce terms), that is:

EX Works (named place). Risk transfer: from the seller to the buyer when the goods are transferred at the disposal of the buyer. Export customs formalities: seller's responsibility. Import customs formalities: seller's responsibility.

FCA- Free Carrier (named place of delivery) Risk transfer: when the goods are transferred at the disposal of the carrier at the warehouse of the seller. Export customs formalities: seller's responsibility. Import customs formalities: buyer's responsibility.

DDP - Delivered Duty Paid (named place of destination)

Risk transfer: when the goods are transferred at the disposal of the buyer. Export customs formalities: seller's responsibility. Import customs formalities: seller's responsibility.

The department of export and import operations. Task: customs clearance and other customs formalities, transportation, accounting reports on primary products provided by a customer addressed to the customs and tax inspectorate.

There are necessary documents required from such establishments: phyto-quarantine inspectorate, ecological inspectorate, sanitary inspectorate, certification office.

The main problem of such a department arises with processing primary products of foreign origin on the territory of Ukraine, because the primary products provided by a customer are imported for a certain period of time and when it is over, the remains of these products should be given the customs clearance and value-added tax (VAT) should be paid.

Costs:

1. calculation and payment of the customs duty and VAT;

2. costs for cargo insurance;

3. vindictive damages for an invalid commodity code according to Ukrainian classification of commodities of foreign-economic activity;

4. transportation costs;

5. customs clearance of equipment, remains, waste products.

A warehouse is subdivided into a part for materials and assemblies and a part for finished products. For the part of input assemblies four slip roads are provided, which make unloading easier. Average unloading makes up 45-50 trucks a week.
Then the cargo is directed into an unpacking zone, and information about delivery is input into FORS system.

Warehouse costs: 1) mismatch between ordered and delivered quantity of materials. Underdelivery will cause the increase in new order costs, special additional transportation costs, additional costs related to downtime and failures in the production process, staff expenditures. Too large quantity of ordered material causes additional costs related to counting and storing assemblies. 2) costs caused by damaged package include timetable of storekeepers and the employees of the input inspection test department, where the quality of the cargo is checked; costs of sorting and creating pellets.

The solution of this problem depends on the conclusion given by the input inspection test department about the prospects of these assemblies: they can be directed to the production process or the supplier at improving quality, reducing price, having an influence on the closure of the enterprise. 4) payment for services of a person performing sampling audit.

Order department. All data concerning orders, that is, cost of transportation, cargo value, lease of means of transport, transportation tenders, direct import and export supplies, urgent import and export supplies are recorded in the FORS program.

Costs of import and export transportations are calculated for the following year according to the cost and quantity per vehicle:

$$
Q_{v} \cdot C_{o}=C_{o} T \text {, }
$$

where $Q_{v}$ is a number of vehicles; $C_{o}$ is the cost of vehicles; $C_{o} T$ are costs of transportation.

The calculation of packaging materials is performed in relation to metal containers, plastic containers or wooden pallets. Package costs: inventory costs. Leoni Wiring Systems and its parent company in Germany annually make an inventory of reusable packaging and, when the lack of this package occurs, Leoni Wiring Systems pays the additional costs according to the bills from the parent company.

$$
R_{a p c}=S_{c}+I_{c},
$$

where $R_{a p c}$ are rental annual package costs; $S_{c}$ are statistical costs; $I_{c}$ are inventory costs.

For the calculation of package rent costs per one truck the following correlation is used:

$$
C_{r p} T=C_{p r} / Q_{v},
$$




\section{Methodology of calculations of logistic costs and charges for delivery}

where $C_{r p} T$ are costs for package renting per one truck; $C_{p r}$ are costs for packsge renting; $Q_{v}$ is a number of vehicles.

For calculating costs for package renting for the following year the following formula is used:

$$
B=Q_{v} \cdot C_{p r}
$$

where $B$ is a following year budget for package renting; $Q_{v}$ is a number of vehicles; Cpr are costs for package renting.

Determination of logistic costs of "LEONI Wiring Systems": Total logistik costs; Freight in; Collecting Costs; inbound costs; Express freight inbound; Recovery of freight in; Recovery of freight in; FREIGHT OUTWORDS; Outbound costs; Express freight outbound; Recovery of freight out; Packaging material; Customs Duty; Personnel Costs (Logistics Employees); Extra costs to be invoiced to oth. Entities; Produced NHs incl. sub contractor; Logistics Employees; Costhour; Total Sales; \% - Anteil.

Logistics costs have their peculiarities comparing to the general costs of the enterprise, because they occur at practically all stages and operations of goods production and selling. It would hardly be denied, that nowadays their amount is dramatically growing, and the problem of managing them efficiently becomes more and more actual. Besides, it is very difficult to select them from the general costs of the enterprise and, naturally, analyze them, which is caused by the specific features of domestic accounting policy.

In accordance with the kind of activity, geographical situation, volume of enterprise activity and other characteristics, every industrial enterprise reckon some part of its costs towards so called "logistic costs". Their amount can differentiate from $5 \%$ to $45 \%$ and can increase under the influence of internal and external factors.

Today there is no developed methodology which would allow selecting logistic costs. But those scientists who had investigated the problem made it possible to determine their specific weight in the structure of the general costs.

If it is commonly accepted that logistic system is a set of interconnected links, the characteristics for its estimation should be considered according to each of them. The integral indicator of reliability of the logistic system of the enterprise will be described as

$$
L_{I N}=[A, B, C, D, \mathrm{E}],
$$

where $A$ is supply; $B$ stands for production; $C$ is transportation; $D$ is storage; $E$ is marketing.

At the next stage a database is formed with the chosen indicators of estimation on the basis of principal accounting forms of the enterprise, namely, balance and financial account. The proposed methodology of reliability estimation is based on the analysis of the structure of logistics costs in relation to profit

For the estimation of the reliability of the logistic system of the enterprise it is necessary to carry out investigations for each of following groups of indicators

$$
N \Lambda_{\mu}=\frac{\sqrt{\sum_{t=1}^{n}\left(S_{i}-S\right)}}{S},
$$

where $S_{i}$ is the investigated indicator in the $i$-th period; $S$ is the mean value of investigated indicators (for all enterprises chosen for the analysis), $i$ is the period of investigation in years; $m$ is the number of indicators for the estimation $(m=1 \ldots n)$; $\mathrm{I}$ is a number of investigated enterprises.

The basis for the result obtained is the matrix of indicators $(m)$ for each enterprise $(i)$.

Taking into account mentioned above, we can assume that complex indicator of reliability of the logistic system of a given enterprise can be calculated by a formula:

$$
L_{K}=5 I_{A} \cdot I_{B} \cdot I_{C} \cdot I_{D} \cdot I_{E},
$$

Then, the next stage of calculating of the reliability of the logistic system of the enterprise assumes forming the integral indicator (for all enterprises)

$$
L_{I N S}=e R_{I N S I} \cdot R_{I N S 2} \cdot \ldots \cdot R_{I N S n},
$$

where $L_{I N S}$ is complex indicator of reliability of the group of chosen enterprises; $R_{I N S 1} \cdot \ldots \cdot R_{I N S 2} \cdot \ldots \cdot R_{I N S n}$ is the indicator of the reliability of each chosen enterprise.

The range of the complex indicator of the reliability level estimation according to the degree of risk is determined by the technique often used at the production enterprises, whose activity is connected with different risks.

So, this technique can be basic for the estimation of the reliability of the logistic system of the enterprise. Its main advantages are its complex character; high accuracy of the results of the investigation which enables us to trace how each element of a complex influences the level of reliability of the logistic system as a whole. This 


\section{O. Ye. Kuzmin, O. Telishevska}

can help us develop such a model of control, which will respond to changes and give information about possible alternative ways of management and be useful for the improvement of the logistic system of the enterprise.

As I.Antoniuk states, at the international level logistics is quite different comparing to the domestic one, because we can note not only changing delivery location [6].The most important differences in this case are:

- as a rule, logistic flows at the stage of international cooperation are related to much bigger order volume than the order deliveries on the certain domestic market;

- international markets are more diverse.

While delivering primary products or assemblies from these markets, as well as delivering goods to them, we should consider more variants of delivery, estimate variants with more resellers, than in the case of "closing" logistic flows only on the certain domestic market.

The primary and the most important stage of monitoring the logistic costs of the enterprise operating on the external market is their identification and estimation. The identification and estimation should provide:

- exploring all theoretically recognized and practically confirmed components of logistic costs according to their classification;

- well-reasoned sequence of calculations of all components of logistic costs and determining their values;

- recording and analyzing semistructured components of the logistics costs; estimating the level of logistics costs of the enterprise [7].

So, on the basis of considered information it can be stated that logistic costs are versatile and cover almost all kinds of activity of the enterprise. That is why they are influenced by many different factors of domestic and foreign economic environment. This causes the necessity of strict control over logistic costs, because any change of a factor can provoke the increase or decrease of general logistic costs which, in its turn, will change the financial results of the logistic system operation. Therefore, logistic costs should be precisely structured, continuously controlled and analyzed for timely elimination of problems of managing enterprise costs.
Conclusions. Market environment requires timely application of the optimization methods for the efficient management of the enterprise activity. It is the most important thing for those enterprises which are losing their competitive ability on the market. The main direction for them should be the continuous adaptation and improvement of the modern methods for the best and the quickest creation of effective economic competitive ability regarding other business entities, as well as advantageous pricing policy for the range of goods and services addressed to their customers.

Regardless to the objectives posed by establishments or enterprises, they always compare two criteria of receipts and expenditures. If receipts imply some positive prospects for the enterprise, costs correct them depending on the impact of external and internal factors of the operational environment.

Today the task of optimization of total costs is still one of the most actual for the top managers of Ukrainian enterprises, especially for those working on the dynamically developing markets. Of course, any optimization of costs couldn't be executed without taking into account the factors which impact these costs. Thorough consideration of factors influencing logistic costs can stimulate making timely management decisions. On the basis of the considered information we can draw a conclusion that total logistic costs are affected by material flow all logistic activity and the most important factor is the time of movement of material flow of the logistic system and spatial arrangement of production enterprises, suppliers, consumers and manpower resources.

It should be mentioned that the optimization of enterprise costs can be realized in the conditions of decreasing or maintaining costs at the increase in the economic management efficiency, as well as decreasing costs at the stable management efficiency (applicable only for short time spans). For domestic enterprises the elimination of the unnecessary costs is undoubtedly one of the main economic problems which can be solved by the correct calculation, account, planning and analysis of the logistic costs, which in turn will allow effective regulation of total costs and more reliable planning of finance indicators of enterprise activity. That is why the correct identification and estimation of particularly logistic costs and timely and rational management in the frame of logistic 


\section{Methodology of calculations of logistic costs and charges for delivery}

system and total costs of the enterprise is the most important because of the fierce competition on the modern world market.

\section{References}

1. Bakajev O. O. Teoretychni zasady logistyky : pidruchnyk dla studentiv ekonomichnych $i$ transportnych specialnostej / Bakajev O. O., Kutakh O. P., Ponomarenko L. A. - K. : Feniks, 2003. - Vol. 1.

2. Bowersox Donald J. Logistika : Integrirovannaja tsep postavok [perievod s anglijskogo] / Bowersox Donald J., Closs David J. - M. : ZAO "Olimpbiznes”. (Original work published 1996). - 2001.

3. Frolova L. V. Logistychne upravlinnia pidpryjemstvom : Teoretyko-metodychni aspekty / L. V. Frolova. Donetsk : Don Duet, 2004.

4. Svyrydko S. V. Upravlinnia nadijnistiu logistychnoji systemy metalurgijnoho pidpryjemstwa / S. V. Svyrydko // Economichnyj Prostir : Zbirnyk Naukowych Prac. - 2006. - № 18. - S. 253-257.

6. Chornopyska N. V. Metodychni pidkhody ociniuvannia logistychnoji dijalnosti pidpryjemstva / N. V. Chornopyska // Visnyk Natsionalnoho Universytetu “Lvivska Politekhnika”. Logistyka. - 2003. № 623. - S. 265-271.

7. Kuzmin O. E. Integralnyj metod ociniuvannia stabilnosti rozvytku nacionalnoho hospodarstva $v$ umovakh postindustrialnoho suspilstva / O. E. Kuzmin, O. V. Pyroh // Aktualni Problemy Ekonomiky. 2012. - № 4 (142). - S. 88-103.
8. Ustenko M. O. (2012). Suchasni tendenciji rozvytku svitovoji logistychnoji systemy / M. O. Ustenko // Visnyk Ekonomiky Transportu i Promyslovosti. 2012. - № 37. - S. 79-81.

9. Kryvovjaziuk I. V. Upravlinnia nadijnistiu logistychnoji systemy pidpryjemstwa /I. V. Kryvovjaziuk, Ju. M. Kulyk. - Lutsk : Lutskyj Natsionalnyj Technichnyj Universytet. - 2012.

10. Pomirko N. M. Klasyfikacija logistychnych vytrat u formuwanni systemy upravlinnia nymy na promyslovomu pidpryjemstwi / N. M. Pomirko // Visnyk Natsionalnoho Universytetu "Lvivska Politekhnika". 2010. - № 669. - S. 99-107.

11. Sahajdak-Nikitiuk R. V. Aktualnost i osobennosti strukturizatsii logisticheskikh izdierzhek priedprijatij farmatsevticheskoj otrasli / R. V. SahajdakNikitiuk // Vestnik SevNTU. Serija Ekonomika $i$ Finansy. - 2011. - № 116. - S. 180-184.

12. Ministerstwo finansiv Ukrainy (27 chervnia 2013). Pro zatwerdzhennia metodychnych rekomendacij shtchodo oblikowoji polityky pidpryjemstwa ta wnesennia zmin do dejakych nakaziv Ministerstwa finansiv Ukrainy vid 27 chervnia 2013 roku № 635. Retrieved from http://www.minfin.gov.ua/control/uk/publish/

13. Rudnichenko Je. M. Logistychni vytraty pidpryjemstwa: Analiz skladu ta struktury / Je. M. Rudnichenko, N. I. Gavlovska // Ekonomika. Menedzhment. Pidpryjemnyctvo. - 2011. - № 23(11). - S. 172-179.

14. Viechkanov T. S. Ekonomicheskaja biezopasnost : uchebnik dlia vuzov / T. S. Viechkanov. - SanktPeterburg : Piter, 2007. 
